Article

\title{
"Sometimes Your Memories Are Not Your Own": The Graphic Turn and the Future of Holocaust Representation
}

\author{
Victoria Aarons $(\mathbb{D}$ \\ Department of English, Trinity University, One Trinity Place, San Antonio, TX 78212, USA; vaarons@trinity.edu \\ Received: 10 October 2020; Accepted: 9 November 2020; Published: 13 November 2020 \\ check for \\ updates
}

\begin{abstract}
The legacy of the Shoah" writes Eva Hoffman, a child of Holocaust survivors, "is being passed on to ... the post-generation ... The inheritance ... is being placed in our hands, perhaps in our trust." We are entering an era that will witness the end of direct survivor testimony. As we move farther and farther from the events of the Shoah, subsequent generations, who see their own lives shaped by the defining rupture of the past, continue to respond to the call of memory. The current era has seen a burgeoning of Holocaust literary representation in the evolving genre of graphic novels, narratives that reanimate and materialize the past through the juxtapositions and intersections of text and image. Calling upon the Deuteronomic imperative to "teach your children," second and third-generation Holocaust writers, through the hybrid form of the graphic novel, attempt to give shape to the traumatic imprint of the Shoah and its haunting aftermath for generations extending beyond that history.
\end{abstract}

Keywords: graphic novels; Holocaust; testimony; Shema; witness; memory; trauma

\section{Introduction: The Imperative to Remember}

Amy Kurzweil, the granddaughter of Holocaust survivors, in the 2016 graphic memoir Flying Couch, sets her grandmother's story against the backdrop of the ancient Deuteronomic imperative to "teach your children" to transmit and reanimate the stories of the past, as Kurzweil's autobiographical narrator puts it, thus "making the unseen visible" (Kurzweil 2016, p. 51). In the graphic memoir, stories are made visible through the intersection of text and iconic representation, a dialogic interplay of polyphonic voices and images that bend time and space. Beginning with the narrative of her grandmother's Holocaust past, the Nazi invasion of Poland, the family's incarceration in the Warsaw Ghetto, and her grandmother's escape and fortuitous survival, Kurzweil draws herself sitting before her computer, the book of her grandmother's transcribed testimony in hand, the text of the survivor's narrative made visible. In a discrete circular panel at the top left corner of the page, Kurzweil self-reflexively draws her own hand holding the book of her grandmother's stories, thus encircling and taking hold of her grandmother's testimony. Her hand, as it is placed over the words of her grandmother's transcribed oral history, is a symbolic representation of the generational transfer and the intervention in her own life of the narrative of her grandmother's past. The text is now in her hands, the words inscribed on the pages of her own book. As Eva Hoffman, a child of survivors, puts it, "The legacy of the Shoah is being passed on ... . The inheritance ... is being placed in our hands, perhaps in our trust" (Hoffman 2004, p. 187). Thus, post-Holocaust generations, in mediating and interceding on behalf of memory, become potentially a "bridge between the real and the unimaginable" as Kurzweil suggests, "between all we've lost ... and what we can't get rid of" (Kurzweil 2016, pp. 47-49). In other words, the stories of the past, as they take root in the imagination of subsequent 
generations, become a means of measuring the irretrievably lost and the haunting, obligatory legacy of the extent of that loss.

Post-Holocaust writing, in many ways, attempts to suture the gap in these fractured narratives of the past. Holocaust literature in its varied structures is a genre of rupture, a performance of the traumatic history it evokes (Aarons 2014, p. 27). As we move farther and farther from the events of the Shoah and from the aftermath of war, modes of witnessing extend and are refashioned in an attempt to broaden their reach, as subsequent generations, who see their own lives shaped by the defining events of the past, take up the transmission of memory and narrative. The current era has seen a burgeoning in Holocaust literary representation in the evolving genre of graphic novels, sequential narratives that draw upon the formal conventions of comics in the fusion of text and image. Increasingly second and third-generation comics artists are turning toward the graphic memoir as a form of Holocaust representation. Graphic narratives of this kind, that is, those that approach serious subjects of personal and collective histories, are, as comics theorist Hillary Chute suggests, "a form of witnessing" one in which the past is made materially present on the page (Chute 2016, p. 1). Such "visual-verbal" forms of expression embody both historical and individual trauma. Thus, they extend the transgenerational reach of testimony and the inheritance of the memories of those who experienced the events firsthand (Chute 2016, p. 112). Calling upon the Deuteronomic imperative to "teach your children," second and third-generation Holocaust writers, through the hybrid form of the graphic novel, attempt to shape the traumatic imprint of the Shoah and its haunting aftermath for generations extending beyond that history.

Teach your children, the Torah tells us, "take to heart" the covenantal obligations and promises, and "impress them upon your children. Recite them when you stay at home and when you are away, when you lie down and when you get up. Bind them as a sign on your hand and let them serve as a symbol on your forehead; inscribe them on the doorposts of your house and on your gates" (Deut. 6:6-9). The Deuteronomic imperative, the requirement to hear, to commit to memory, and to impart the covenantal design - both "blessing and curse" - to future generations, creates a scaffolding for the construction of collective consciousness and individual conscience (Deut. 11:26). "Hear, O Israel!" the Deuteronomic bard beckons, the herald whose words both summon the past and provide a directive into the future, an instructional guide, "to the end that you and your children may endure ... as long as there is a heaven over the earth," a blueprint for generational continuity and responsibility (Deut. 11:21). This is a narrative, a testimony, whose words are impressed upon its listener, pressed upon the people of Israel, an imprint made permanent, material evidence witnessed with one's "own eyes" (Deut. 11:7).

In Jewish liturgy and lore, the story always matters. Stories, individual histories set against the backdrop of the larger history of Jewish continuity and destruction, survival and loss-midrash and lamentation - take root in the collective memory of the past, both mythic and historical, and cast an imprint and impression on the future. Imparting the stories of the past and their contemporary relevance is deeply rooted in Jewish tradition: "Listen to this", the prophet Joel instructs, "Give ear ... Tell your children ... And let your children tell theirs, And their children the next generation!" (Joel 1:2-3). Stories become texts of continuity, of temporal and spatial modes of symbolic reference. They structure identity. Kurzweil, for example, in an early series of drawings that introduces her graphic narrative, shows the book of her grandmother's stories opening at the top of the page. As the book opens wider, the words tumble out and spiral down the page, gaining momentum, taking shape, forming themselves into a house, the home in which Kurzweil, the grandchild of survivors, comes of age. It is against the fortress of the walls of her grandmother's history that Kurzweil forms her own identity, her developing sense of self and place shaped by her grandmother's memories. The images of the home built from the stories of the past create an ethical framework for living in the future.

There is a kind of talismanic efficacy to the perpetuation and continuation of the story, a narrative without end, words given weight and solidity so that they fall back into the world, the covenant renewed and reinterpreted inter and trans-generationally. The events of the Holocaust interrupted 
this ongoing narrative. They threatened the unfolding of generational continuity, creating a caesura, a rupture in history and in the transmission and exchange of histories, of lives, of communities, and of stories. Post-Holocaust generations, writing in response to the catastrophic rupture of the Shoah, through the legacy of transmission, attempt to suture the gaps, the breaches, and the betrayals in that narrative, "to excavate our generational story from under its weight and shadow" (Hoffman 2004, p. xi). Such attempts at recovery and reanimation require an attentiveness to the memories of those who witnessed the devastating effects of the Shoah, all the more so as we enter an age that will mark the end of direct survivor testimony.

Thus, the third-generation graphic novelist Kurzweil begins the illustrated narrative of her grandmother's traumatic past—-the loss of her family and her own perilous survival—by contextualizing her efforts in the long tradition of Jewish storytelling: "I meant to tell Bubbe that I've been reading her stories, that I plan to write and illustrate her life ... that, in the tradition of curious and dutiful sons and daughters before me, I will polish and publish her history, immortalize it, fashion it into those stories to be imprinted upon our homes and on our gates, as we lie down and as we rise up" (Kurzweil 2016, pp. 50-51). The obligation of each generation to listen, to remember, and to memorialize the narrative of the past elides temporal and experiential boundaries in a refrain that shapes and defines post-Holocaust writing. This is a legacy whose significance predates the young narrator of Kurzweil's graphic memoir; it consists in the felt obligation to remember, to impart, and to transmit the narrative of the past. As she says: "Maybe it's in the blood" a consanguineous, defining legacy bequeathed to her long ago (Kurzweil 2016, p. 51).

Thus, Kurzweil will follow the Deuteronomic injunction. She will "listen"; she will "hear" her grandmother's stories of devastation, loss, and survival and internalize them, immortalizing and commemorating her memory and the memory of those who perished. The Deuteronomic imperative to remember is a guiding framework, a touchstone for the structural, metaphorical, thematic, and potentially therapeutic return to the past in second and third-generation Holocaust narratives. The obligation to participate in the ongoing memory of the past connects the descendants of Holocaust survivors to a narrative history that is not their own; it is a memory and testimony transferred. As time lapses, these are memories that are increasingly mediated, memories of stories told, stories of memories told and retold. These are narrative accounts replanted in the imagination of subsequent generations, memories aroused and imparted, a continuing intra and trans-generational dialogue. Second and third-generation Holocaust graphic novelists, through the juxtaposition of word and image, create a mediated visual witnessing in which individual stories of families are set against the larger history of the Shoah, individual memories that are refracted through eye-witness accounts and reframed, reshaped through the intercession of subsequent generations. As the Holocaust survivor in Martin Lemelman's second-generation graphic memoir Mendel's Daughter beseeches her son, "Listen to me, Mattaleh! Sometimes your memories are not your own" (Lemelman 2006, p. 4). Her entreaty and command, "Listen to me!" evokes the ancient prayer of the Shema, the mandate to listen, to hear, to heed, and to enter the space of memory. In responding to her behest, the child of Holocaust survivors will extend the survivor's eye-witness testimony, a story that, after her death, he now must tell.

\section{The Graphic Turn}

The early decades of the 21st century have seen a turn in Holocaust representation to increased experimentation with the medium of graphic novels. The publication of Art Spiegelman's iconic two-volume Maus, the graphic account of his parents' Holocaust history drawn in the medium of comics, largely defined the possibilities of the genre. Maus, the first graphic novel to receive a Pulitzer Prize (1992), transformed the formal structures of comics into a medium for the serious expression of traumatic histories, authenticating and expanding the genre to include the labyrinthine terrain of Holocaust memory. With its animated temporal juxtapositions of past and present and its polyvocality and doubling of generational voices, Maus not only reimagines, in the sharp executions of image and text, the catastrophic rupture of the Holocaust, but extends the traumatic imprint of the Holocaust 
as it lays claim to the descendants of Holocaust victims and survivors. As Chute suggests, Maus, like other nonfictional documentary comics, in the fluid temporal shifting and multi-voiced expression of historical rupture, extends our understanding of both testimony and witnessing. As she explains, such textual/visual conceits "double the act of witness ... They do not conceal or cloak trauma, but rather put its elements on view" (Chute 2016, p. 233). Maus, as the first Holocaust graphic narrative to receive widespread critical acclaim, thus provided graphic novelists and illustrators with an opening, with "permission" as child survivor and cartoonist Miriam Katin puts it, to tell their own stories of survival and devastating loss through the medium of comics (Gravett 2015). Ever since Maus, and most notably in the opening decades of the 21st century, a significant number of graphic narratives that return to the traumatic memory of the Shoah have been published in the United States and abroad. These texts speak to an important direction in and extension of Holocaust representation at a transitional moment in history. How do we talk about the Holocaust now at a time that will see the end of unmediated eye-witness testimony, when having seen, as Elie Wiesel once wrote, "with my own eyes" becomes replaced with a refracted, kaleidoscopic witnessing, an imaginative envisioning of the past through the lens of second and third-hand memories, memories dimmed, deferred, and eclipsed by time (Wiesel [1958] 2006, p. 32)?

Thus, in contemporary Holocaust writing, the multigenerational scaffolding of the intersections of histories and lives, along with the Deuteronomic imperative to listen, to remember, and to transmit the story, either implicitly or explicitly becomes the frame for the evocation of past memories, a past reimagined and reanimated. The Deuteronomic command to hear, the basic declaration of faith, as it extends beyond its scriptural source, is the originating referent for the call to remember, a reminder of one's obligations to collective memory. It is a faith placed in voice, in ongoing testimony, wherein, as memoirist Daniel Mendelsohn suggests, "time and space, distance and proximity, become confounded" a narrative space in which the past is recalled and reanimated (Mendelsohn 2006, p. 88). As Mendelsohn explains, "we always turn around to stare at what lies behind us, which is to make an impossible wish, a wish that nothing will be left behind, that we will carry the imprint of what is over and done with into the present and future" (Mendelsohn 2006, p. 503). Thus, the imprint of the past becomes a blueprint for post-Holocaust generations, the backdrop, as Hoffman poses, for "a whole generation's store of imagery and narration, the icons and sagas of the post-Holocaust world" (Hoffman 2004, p. 11).

These are narratives that begin with journeys into the largely unknown terrain of Holocaust memory, actual and imagined. As Jonathan Safran Foer writes, in the novel Everything is Illuminated, the story of a young man in search of his grandfather's Holocaust past, "the beginning of every story is an absence", an opening in the narrative, a fissure born of rupture and loss (Foer 2002, p. 230). In response to the ever-widening caesura, post-Holocaust generations attempt to reanimate and revocalize that space of interruption, the ever-widening distance between the eye-witness and those who came after, those for whom memories of the Shoah, as Marianne Hirsch puts it, "are mediated not by recall but by imaginative investment, projection, and creation" (Hirsch 2012, p. 5). Such stories must be imaginatively stitched together, made whole but, at the same time, perform the fragmentation, tears, and erasures of individual and collective histories, "in an attempt to create a unified narrative out of fragments ... a postscript to loss" (Aarons and Berger 2017, p. 5). As the granddaughter of the Holocaust survivor in Kurzweil's graphic narrative acknowledges, "Our conversations are always in fragments, like my knowledge of [her grandmother's] life" (Kurzweil 2016, p. 32). However, these are structured interruptions. Broken, severed narratives become openings for reframed stories; time collapses in on itself creating the conditions for an unfolding transgenerational dialogue.

\section{Reanimating the Posthumous Voice: Mendel's Daughter}

Martin Lemelman's 2006 graphic memoir Mendel's Daughter is the illustrated narrative of his mother's videotaped testimony of her life leading up to and during the war. Beginning with the graphic depiction of the ordinary rhythms of his mother's prewar domestic life, Lemelman shows 
the violent onslaught of the Nazi invasion of Poland and the devastating consequences that followed in rapid succession - "the world," as she knew it, "going under": the rise of overt antisemitism and antisemitic legislation; the capture, deportation, and murder of members of her immediate family; her precarious escape and concealment in a hole dug in the forest, a "grave" that she inhabited with her sister and two brothers; and her eventual survival, "out from the forest, into the light" (Lemelman 2006, pp. 115, 147, 176). Lemelman commits his mother's memories to the page in soft black and white drawings, images that lay claim to her testimony. These are images that, along with the transcribed text of her narrative, provide material evidence to the traumatic events that she witnessed, as she laments, "I saw all this, and I hear all this" (Lemelman 2006, p. 115). As Chute suggests, graphic narratives that bear witness to the traumatic past "materially retrace inscriptional effacement; they repeat and reconstruct in order to counteract" (Chute 2016, p. 4). Such testimony embodies past trauma and gives substance to memory. As Chute puts it, "'Materializing' history through the work of marks on the page creates it as a space and substance, gives it a corporeality, a physical shape" (Chute 2016, p. 27). Mendel's Daughter is thus a living testament to Lemelman's mother's memories but also to the family he never knew, grandparents and other members of his extended family he might have known save for the atrocities of history.

Lemelman only returns to the tape of his mother's testimony, the video that he recorded of his "mother talking about her life," years after her death (Lemelman 2006, p. 5). Thus, in summoning the posthumous voice, in "activating the past on the page," Lemelman actualizes and authenticates his mother's story (Chute 2016, p. 27). As he said in an interview, "I want people to know these events are real, to look at the book and say, 'This really happened. The Holocaust really happened'" (Berk 2006). In introducing his mother's narrative, Lemelman, in the opening pages of the graphic memoir, draws two sequential images of his own hand holding the audio tape of his mother's testimony and inserting it into the video player. It is through his volition that she is given new voice. However, while Lemelman is the creator of the book, this is Gusta Lemelman's story; it is "just her voice" that that we will materially "hear" transcribed on the page (Orbach 2010). For, as Lemelman insists in a panel that is centered beneath the two images of his hand retrieving the videotape and putting it into the player, "This is her story. It's all true" (Lemelman 2006, p. 5). In this final image on the page, Lemelman draws a self-portrait of his visage facing forward, his eyes slightly askance as they are diverted off the page, looking toward the narrative that will follow. In this panel, he draws himself with his back to a mirror; we see simultaneously the front and back of his head. He is posed forward as, with trepidation, he is looking back, an introduction to the horrors that will materialize on the following pages. This image signifies a pause in the narrative. His dual reflection represents a moment of hesitation on the part of the son of survivors: to look ahead, to an as-yet-undetermined future, unbeholden to the events of his mother's history, or to look behind, to be taken in by the past. The multidirectional image of the author/illustrator's face, as Jessica Lang suggests, represents "the fractured nature of postmemory, the province of the second generation" (Lang 2017, p. 66). That is, the son of Holocaust survivors, at this moment of uncertainty and hesitation-where and how to look-reflects "the fractured position from which one views memories that are not one's own but that form a significant part of one's legacy and identity" (Aarons 2020, p. 55). This is the last image we see before Lemelman turns the telling over to his mother, the legitimate storyteller and rightful owner of the narrative. While her voice will guide us through the narrative, the graphic artist will provide the material shape to her story. Lemelman thus promises to make visible that which now only exists through the found voice of the survivor's recorded memory.

Such an intergenerational negotiation is characteristically performed by way of the recurring trope of prosopopoeia, the metaphorical reanimation of the dead, an awakening of the found voices of the past. Prosopopoeia is a figure that gives presence to absence, and, in doing so, as Susan Gubar suggests, "allows the authors who manipulate it to summon the posthumous voice, to conceive of subjectivity enduring beyond the concentration camp, and thereby to suggest that the anguish of the Shoah does not, and will not, dissipate" with time and distance (Gubar 2001, p. 192). In creating 
"a language for the staggering horror" of the enormity of the Shoah, the trope performs, as Gubar argues, a kind of "proxy-witnessing" (Gubar 2001, pp. 191, 193). In conjuring the absent voice, the metaphorical summoning paradoxically represents for the moment of narrative intervention that which was irretrievably lost, a space in which, as Israeli novelist David Grossman writes, "both the thing and the loss of it can co-exist" (Grossman 2008, p. 13). To reconstruct and summon the traumatic past is, as second-generation graphic artist Bernice Eisenstein proposes, "to step into the presence of absence" thus holding in tense suspension, paradoxically, both presence and absence, both the embodied subject and the loss of it (Eisenstein 2006, p. 167). As Gubar suggests, "Bestowing presence onto the absent dead is inherently oxymoronic"; the imagined evocation of those who were once alive, active and present, makes all the more apparent their absence" (Gubar 2001, p. 197). The recurring figure of prosopopoeia is thus a trope of both tension and relief, metaphorically representing both the voice of the absent figure and the tragic loss of it. The evocation of the posthumous voice is not simply a kind of ventriloquism. The writer/graphic artist or narrator is not speaking in or through the voices of the dead. As Elie Wiesel once cautioned, "no one has the right to speak on their behalf" (Wiesel 1990, p. 194). Rather, these graphic memoirs create the conditions in which to give voice back to the dead in the reimagined material image of those who can no longer speak for themselves. Thus, we see a recurring conceit in these second and third-generation graphic novels in which the graphic artists visually reproduce the transcribed or recorded words of survivors, making claims for their unmediated testimony. Kurzweil, for example, in gesturing to the authenticity of witnessing, turns the telling over to the survivor who, in her own words, extends the promise of direct testimony: "Oh I could tell you so many stories, I have stories and stories. A thousand and one stories ... " (Kurzweil 2016, p. 58). Perhaps then, as Gubar proposes, the trope of prosopopoeia can serve as a testimonial directive, the extension of the imperative to hear, an invitation to "living readers to be morally and historically instructed by overhearing the voices of the dead or dying" (Gubar 2001, p. 194). These writers/graphic artists are not speaking for the dead. They create the conditions so that the dead may speak.

Thus, in reclaiming and reanimating his mother's voice, Lemelman, in Mendel's Daughter, concurrently evokes, as cartoonist and comics theorist Scott McCloud suggests, "the seen and the unseen. The visible and the invisible" (McCloud 1993, p. 92). In creating this liminal space, the graphic artist sets the stage for the narrative that will follow, visually and textually reconstructing the absent presence of past events and those who witnessed them. In turning over the narrative to the survivor, Lemelman creates an immediacy and proximity to otherwise remote events. This is a complicated temporal and spatial exchange, one that anticipates the silence, the narrative end that it momentarily forestalls.

At an important temporal moment in the memoir, Lemelman draws an image of his mother and her immediate family - her parents and five siblings_as they sit at the kitchen table for what will become their last meal together, forecast by his mother's understated words: "we eat for one last time in our house .... And good-bye. We go" (Lemelman 2006, pp.186-187). This panel harkens back to a previous image that reflects an earlier, happier time in Gusta Lemelman's family life, a childhood filled with the sensations and security of ordinary rhythms and rituals: "every day," she longingly recalls, "from when I was little, until I was big, we all woke up ... . We have ... cereal, bread and butter and milk for breakfast ... . It was beautiful to look out our kitchen window in the summer ... . We have a big garden ... all the way until the railroad tracks" (Lemelman 2006, pp. 13-14). The first image of the family at the breakfast table is nearly identical to the image that intrudes on the narrative later, save for the dramatic rupture signaled in its second iteration. This is an impending moment that we should have anticipated, for, as Gusta warns her implied listener earlier in the narrative, the train tracks that abut the family's property lead to the train's final destination, "the stop ... that they put the Jews in the cars and take them away" (Lemelman 2006, p. 14). Thus, this deceptively ordinary domestic scene of the family gathered together around the table stages their final moments together and anticipates the rupture and dismantling of their lives that is soon to come. 
When this image reoccurs later in the narrative, the seeming ordinariness of this moment-children and parents in conversation at a table laden with food-is undercut and destabilized by the violence superimposed on the scene. For here Lemelman draws the family disappearing. Five of the figures, Gusta's parents and three of her siblings, guided by his mother's words, are simultaneously drawn by the graphic artist as they are in the process of being erased. In representing their impending deaths, Lemelman smudges their figures; they are erratically latticed with erasure lines that blot out and blur their images. The erasure marks crisscross the figures in jagged slashes that represent the violence and abruptness with which the family was dismantled. This is a remarkable, if understated, graphic representation of a family coming undone. This is a very disturbing image, one that creates the liminal moment before the family, still together, will be shattered. Lemelman's mother's immediate family, as we witness them, dissolves before our eyes. In representing both presence and absence simultaneously, the graphic artist, by partially erasing what he has drawn, becomes a secondary, surrogate witness to the family's disintegration and the violence done to them. Lemelman, as second-generation witness, participates in the narrative, both recalling his extended family to life and reckoning their loss, a loss that becomes his own. No longer distinctly visible, their blurred images are opaquely present. That they are not entirely absent from the picture, but in the process of being erased is significant here. This is an image of the family cleaving, splintering, the gerund signaling that they are on the threshold of departure and obliteration. However, they remain, still, in memory.

The temporal threshold establishes a tense proximity and immediacy to the moment of discovery. Time itself is eroding as it is reconstructed. Temporality is an unstable category here. Lemelman draws time metaphorically retreating and advancing. The borders of the panel in which the diminishing family is portrayed are not distinctly delineated. Rather than keeping the image contained within the frame of the panel, the shadowy image extends beyond the edges of the rectangular panel. On either side, the image, as it softens and pales, moves outside the structural container of the frame. Here, the spatial extension suggests a temporal elasticity, a fluid blurring and blending of past, present, and future. As we face the image, the drawing as it extends beyond the left facing border, harkens to the past, to a time before the rupture of the family. The occasion of this image calls forth the earlier drawing of the intact family. In doing so, it signals the time before the Nazi assault on the Jews, a reminder of prewar life and the tenuousness of it. As Lemelman explained in an interview, he wanted to achieve "realism ... to know about these specific people ... where they lived ... to portray the family ... before the war" (Cohen 2008). However, here Lemelman also extends the drawing into the future. On the right facing side of the panel, the image escapes the boundaries of the frame, lengthening, stretching, reaching beyond the panel and moving toward the subsequent page, the future as yet unknown to the family but known to us.

In showing time elapsing and elongating, Lemelman both compresses and expands it, altering time's dimensions, creating a different kind of temporal space. He establishes what Art Spiegelman defined as the super-present, a narrative and visual moment in which time is coalesced and layered (Spiegelman 1994). The super-present creates a kind of metaphorical hovering above, time suspended and spreading in a panoramic vision of past, present, and future. "Super", after all, refers to a condition of being "over" or "above", "higher." As Erin McGlothlin suggests, the "super-present ... seems to occupy a place outside the movement of life, in a static space that is not the antithesis of life, but a place where life's ebb and flow do not reach ... a sort of timelessness ... .a narrative time in which nothing exactly happens" but, I would add, a space in which everything happens, a temporal space that reanimates the past and moves us into the devastating future (McGlothlin 2003, p. 178). It does so all the while suspending us in the narrative present, that of the survivor's recorded story that exists somewhere out of time and space and the narrative moment of the second-generation graphic account. In joining temporal moments, Lemelman gestures toward the work of memory. The murdered members of his mother's family exist in the indistinct borders of the page and in the receding echoes of memory. Here we find something akin to what Gubar says of the language of poetry, wherein images and words "composed in the cadences of the dead and dying emanate an unnerving, 
invented proximity" (Gubar 2001, p. 193). While Lemelman's mother, the last of the family who in actuality could remember them, is no longer living, her son will recreate their once-presence and, at the same time, memorialize their deaths. Thus, in this and other like images, we find an invitation to continue testimony.

\section{The Limits of Representation}

The conventions of the graphic narrative-the materializing of voices and images-create a representation of visual-verbal testimony, one that invites the reader/viewer, through tropes of both presence and absence, to participate with the graphic artist in a kind of vicarious, proxy witnessing. At the same time, however, such structures expose the inevitable limits of representation. For, while past trauma is evoked to make imperative, through the summoned voice of the eyewitness, as Kurzweil says, the memory "of things we'd rather have forgotten ... or couldn't understand," such forms of representation are challenged by the unbridgeable distance between those who experienced the events of the Shoah directly and those for whom such memories are the stuff of the imagination (Kurzweil 2016, pp. 44-45). Such tropes and designs are no more than substitutions. At best, such attempts at proximity, immediacy, and reanimation are meager, if uncanny, substitutes for those worlds, communities, lives, and stories that were irretrievably destroyed.

In the 2006 graphic novel I Was a Child of Holocaust Survivors, the second-generation Canadian graphic artist Bernice Eisenstein draws and narrates the twined stories of her parents, Barek (Beryl, Ben) and Regina Eisenstein, survivors of Auschwitz and Birkenau, and the influence of their Holocaust histories on the fashioning of her own identity. As the child of survivors, as she acknowledges, her perception of the world she inhabited was "always accompanied with an undercurrent of loss", a felt sense of absence and longing that "inevitably shadowed the landscape" of her life (Eisenstein 2006, pp. 24, 27). The graphic novel traces her efforts to fill in the missing pieces of her parents' narratives, to suture the gaps in her fragmented knowledge of their past, "to step into the presence of absence", as she puts it (Eisenstein 2006, p. 167). In a narrative that moves back and forth in time, Eisenstein recreates the stories she has unearthed, "to fill in the parts ... that had gone missing ... replacing absence with memory" (Eisenstein 2006, p. 18). Her found knowledge of her parents' past, however, is partial, foiled by the accidents of birth, by her own place and time, born on another continent and too late to remember, never having witnessed the horrors that her parents experienced.

At a critical juncture in the graphic novel, Eisenstein draws a black and white image of a concentration camp barracks enclosed by barbed wire fencing (Eisenstein 2006, p. 115). In this stark, solitary image that exists on the page without text, Eisenstein creates the impression of a three-dimensional landscape. In the background are barracks, within which we can faintly make out indistinct features of prisoners trapped behind barred windows. The faces of the inmates are intentionally blurred, distorted, huddled together, each window reflecting a mass of indistinguishable, featureless bodies. This sense of helpless desolation evokes the haunting words of Primo Levi's poem "Shema": "Consider whether this is a man/ ... Consider whether this is a woman/Without hair or name/With no more strength to remember/Eyes empty and womb cold" (Levi [1993] 1996). Against this bleak scene, in the foreground of the image of the brick fortresses stand trees, their barren limbs reaching upward beyond the borders of the panel. Stripped of all foliage, they stand bent, denatured. Extending horizontally across the panel are three rows of barbed wire fencing that stretch outside of both sides of the frame. The symmetry in the drawing's parallel design, with the likeness of the trees extending and the fence elongating, is striking: the barren outstretched tree limbs extending upward, vertical embodiments of despair; and the barbed wire's embankment, not unlike the barren, jagged extensions of the branches that reach, like flames into the clouded, ashen sky, horizontally enclose the scene in a terrible tableau of annihilation. The jagged spikes of the trees resemble the bent spikes of the barbed wire. Both erupt from the frame in implied violence. The layering of barracks, trees, and fencing creates the illusion of depth. This is a bleak, harsh scene set within a silence that anticipates absence. 
There are images that let in and those that keep out. Significantly, while we are invited to witness the horrors implied by this image, as viewers we remain outside the barbed wire boundary that visually separates the distanced reader and the graphic artist, here the child of survivors, from the immediacy and proximate reality of the camps. The faces behind the windows of those who experienced the events firsthand are diminished, small, and indistinct as the events, experiences, and memories recede temporally. The image thus reflects not only the receding range of distance from which we view the Holocaust—-temporally, spatially, and experientially—but also the layers of understanding through which subsequent generations must pass to enter that imaginative space. Such an image suggests both presence and absence, the ghostly remains of the past. It takes away as it offers. As McCloud explains "the art of comics is as subtractive an art as it is additive" (McCloud 1993, p. 85). In Eisenstein's remarkable drawing, addition leads to subtraction. Her pursuit of the past brings her only so close to understanding, to seeing in, for finally that which is irrevocably lost can only be unknowable to one on the outside, as is the sheer weight and magnitude of suffering.

\section{In Conclusion: Shema}

As we began with Kurzweil's promise to fulfill the Deuteronomic imperative, to transmit the history and memory of the Jewish people, to "fashion it into those stories to be imprinted upon our homes and on our gates," so, too, we conclude with the Shema, the prayer to hear, the call to attentiveness (Kurzweil 2016, p. 51). While the ancient Hebraic declaration of the Shema is a testament of faith, of God's singular presence, here, in midrashic moments of interpretation, the Shema is a summons to testimony and a caution against forgetfulness. Both Lemelman and Eisenstein, second-generation graphic artists, end their narratives with the call to memory and the imperative to acknowledge one's inheritance of and place in the narrative of the past, in other words, one's shared suffering. The backdrop of the Shema is thus a cautionary portent against silence.

One of the final series of illustrations in Mendel's Daughter is that of a drawing of four images on the same page of members of Lemelman's mother's family who were murdered by the Nazis: her mother, her father, and her two sisters. As the narrative draws to its inevitable close, the final images Lemelman prosopopoeically conjures are those of the dead. Their unmediated voices tell the story of their own deaths. On a single page are four stacked panels, each panel containing the testimony of one of the victims of the Final Solution. While they are unable to speak of the atrocities they experienced, their words are immortalized on the page. The panels are divided; on one side is an image of the murdered family member, eyes covered; on the other side of the panel are the posthumous words of the deceased, the testimony of each death prefaced with the refrain, "Yes, this happened to me" (Lemelman 2006, p. 217). The images of the hands of the victims covering their eyes as they speak evokes the traditional posture of the recitation of the Shema, but their pose, posthumously recreated, suggests that they cannot bear to see their own end as each person narrates his or her singular death: "I ran and they shot me. I was bleeding until I died"; "I hid, but they found me, and beat me. They took me to Belzec, then Maidanek"; "They took me, and my husband ... and my son"; "I was taken with the Mother"; "They gassed us and burnt us" (Lemelman 2006, p. 217). As this repetitive, understated litany of horrors descends down the page, their testimony comes to an end. What follows is a blank page of silence. Their firsthand testimony is thus an invitation to enter the memory of the past, signaled by the white space of the liminality of the empty page. This moment recalls an earlier image in Lemelman's graphic memoir in which the artist introduces a simple drawing of his mother's parents, eyes covered, bracketed by the opening words of the prayer, "Shema Yisrael" (Lemelman 2006, p. 117). The call to hear, to pay attention, introduces the unstoppable train of horrors that ensues. "Hear, O Israel," as an allegory for collective, participatory conscience, projects the obligatory call to memory for future generations, to heed the testimony of the witness in crucial, living ways. Fittingly, then, the final image in Lemelman's graphic memoir is a return to a previous drawing of his mother hiding in the woods, crouched beneath a canopy of branches. Beneath the iteration of this image, on the final page of the narrative, are the words from the Passover Hagaddah: "In every generation, one must look upon 
himself, as if he personally came out of Egypt", that is, to see oneself as part of the history of bondage but also the legacy of continuity and survival (Lemelman 2006, p. 219).

Eisenstein's second-generation graphic memoir, too, ends with a plea for remembrance. On one of the final pages is a reproduction of the passage from Deuteronomy inscribed in the Hall of Remembrance in the Holocaust Museum in Washington, D.C.: "Only guard yourself and guard your soul carefully, lest you forget the things your eyes saw, and lest these things depart your heart all the days of your life, and you shall make them known to your children, and to your children's children" (Deut. 4:9). These words of caution, a safeguard against forgetting, are suspended above a row of faces of survivors, whose presence is an obligatory call to future generations to commit themselves to memory, "lest you forget" (Deut. 4:9).

Funding: This research received no external funding.

Acknowledgments: I would like to thank David Patterson for his kind invitation to contribute to this important Special Issue of Humanities.

Conflicts of Interest: The author declares no conflict of interest.

\section{References}

Aarons, Victoria. 2014. A Genre of Rupture: The Literary language of the Holocaust. In The Bloomsbury Companion to Holocaust Literature. Edited by Jenni Adams. London: Bloomsbury, pp. 27-45.

Aarons, Victoria. 2020. Holocaust Graphic Narratives: Generation, Trauma \& Memory. New Brunswick: Rutgers University Press.

Aarons, Victoria, and Alan L. Berger. 2017. Third-Generation Holocaust Representation: Trauma, History, and Memory. Evanston: Northwestern University Press.

Berk, Josh. 2006. Interview, "Graphic Novel a Personal, Profound View of the Holocaust.". The Morning Call. Available online: https:/www.mcall.com/news/mc-xpm-2006-12-10-3696246-story.html (accessed on 9 September 2020).

Chute, Hillary L. 2016. Disaster Drawn: Visual Witness, Comics, and Documentary Form. Cambridge: Harvard University Press.

Cohen, Leon. 2008. Artist Sought Realism in Graphic Memoir of his Shoah-survivor Mother. The Wisconsin Jewish Chronicle. Available online: https://www.Jewishchronicle.org/2008/03/31/artist-sought-realism-in-graphicmemoir-of-his-shoah-survivor-mother/ (accessed on 9 September 2020).

Eisenstein, Bernice. 2006. I Was a Child of Holocaust Survivors. New York: Riverhead Books.

Foer, Jonathan Safran. 2002. Everything is Illuminated. New York: Houghton Mifflin.

Gravett, Paul. 2015. Interview, “Miriam Katin: Coming to Terms.". Available online: http://www.paulgravett.com/ articles/article/miriam_katin (accessed on 9 September 2020).

Grossman, David. 2008. Writing in the Dark. Translated by Jessica Cohen. New York: Farrar, Straus and Giroux.

Gubar, Susan. 2001. Prosopopoeia and Holocaust Poetry in English: Sylvia Plath and Her Contemporaries. The Yale Journal of Criticism 14: 191-215. [CrossRef]

Hirsch, Marianne. 2012. The Generation of Postmemory: Writing and Visual Culture after the Holocaust. New York: Columbia UP.

Hoffman, Eva. 2004. After Such Knowledge: Memory, History and the Legacy of the Holocaust. New York: PublicAffairs. Kurzweil, Amy. 2016. Flying Couch: A Graphic Memoir. New York: Catapult/Black Balloon.

Lang, Jessica. 2017. Textual Silences: Unreadability and the Holocaust. New Brunswick: Rutgers University Press.

Lemelman, Martin. 2006. Mendel's Daughter: A Memoir. New York: Free Press.

Levi, Primo. 1996. Survival in Auschwitz: The Nazi Assault on Humanity. Translated by Stuart Woolf. New York: Touchstone/Sion \& Schuster. First published 1993.

McCloud, Scott. 1993. Understanding Comics: The Invisible Art. New York: HarperCollins.

McGlothlin, Erin. 2003. No Time like the Present: Narrative and Time in Art Spiegelman's Maus. Narrative 11: 177-98. Available online: https://www.jstor.org/stable/20107309 (accessed on 9 September 2020). [CrossRef]

Mendelsohn, Daniel. 2006. The Lost: A Search for Six of Six Million. New York: William Morrow/HarperCollins.

Orbach, Michael. 2010. Q and A with Martin Lemelman. The Jewish Star. Available online: https://www. thejewishstar.com/stories/q-and-a-with-martinlemelman,1975? (accessed on 9 September 2020). 
Spiegelman, Art. 1994. The Complete Maus. New York: Voyager, CD-Rom.

Wiesel, Eli. 2006. Night. Translated by Marion Wiesel. New York: Hill and Wang. First published 1958.

Wiesel, Eli. 1990. From the Kingdom of Memory: Reminiscences. Translated by Marion Wiesel. New York: Summit Books.

Publisher's Note: MDPI stays neutral with regard to jurisdictional claims in published maps and institutional affiliations.

(C) 2020 by the author. Licensee MDPI, Basel, Switzerland. This article is an open access article distributed under the terms and conditions of the Creative Commons Attribution (CC BY) license (http://creativecommons.org/licenses/by/4.0/). 